\title{
On Being a Scholar-Practitioner: Practical Wisdom in Action Book Review
}

\author{
Cynthia A. Tananis, EdD \\ Associate Professor, Emeritus \\ University of Pittsburgh \\ tananis@pitt.edu
}

Maria Piantanida, Patricia L. McMahon, and Marilyn Llewellyn: On Being a Scholar-Practitioner, Practical Wisdom in Action. Wisdom of Practice Series, Pittsburgh, PA: Learning Moments Press, 2019. 290 pp. \$22.95 ISBN-13: 978-0997648881

The development of scholarly practitioners for advanced practice through Education Doctorate degrees has become more common (Perry, 2012; Shulman, Golde, Bueschel, \& Garabedian, 2006). Education doctorate programs strive to focus on the differences in training as a researcher-educator via the more traditional doctorate $(\mathrm{PhD})$ and in becoming a scholarly practitioner via the Education Doctorate $(\mathrm{EdD})$. I like to tell my own doctoral students, both $\mathrm{PhD}$ and $\mathrm{EdD}$, that the crux of the difference is a focus on a problem area (for example, marginalization of teachers of color) as the fodder for the $\mathrm{PhD}$, and a focus on inquiry as practice as the purview of the EdD. This assumes that as scholarly practitioners, graduates will regularly identify and systematically inquire about many "problems of practice" that will lead to informed improvement. We envision graduates who have adopted an improvement-centered mindset with the necessary skills and strategies to engage in inquiry-driven action. On Being a Scholar-Practitioner, Practical Wisdom in Action explores both, conceptually and experientially, what it means to "be" such a scholarly-practitioner.

Indeed, as scholarly-practitioners themselves, Piantanida, McMahon, and Llewellyn begin with a "problem of practice" as the impetus for writing the text. As educators, they were troubled by the "persistent narrative about failing skills, teacher flight, and privileging of rules over professional judgement" in schools (p. 5). Further, they took issue with the over-simplification of these complex issues, suggesting the importance of an understanding of context and development of practice-based wisdom in education. Their book explores how best "to create the conditions in which professionals are able to cultivate wisdom" through "embracing the stance of Scholar-Practitioner" (p. 10).

One of the seminal discussions of advanced practice in the professions, including education, is the notion of praxis; of being and caring, beyond the doing in practice (Schwandt, 2002). This stance is important as a foundational element of the book and frames the purpose of the authors, as they suggest that engaging as a scholarly-practitioner "is a way of being, the embodiment of a mindset ... in which action informs understanding and understanding informs action" (p. 3). The resulting sections of the book discuss dimensions of this mindset, both drawing from and creating the practical wisdom which informs daily engagement as an educator. The authors invite readers on a journey of meaningmaking as a "process of always becoming as nascent sensibilities blossom into more robust and nuanced capabilities" (p. 18).

The body of the book invites exploration of components considered critical to a scholarly-practitioner's praxis: pedagogical wisdom, theoretical understanding, contextual literacy, ethical stewardship, metacognitive reflection, and aesthetic imagination. Each section offers two to three chapters that first describe the component and then presents discussion of nuanced praxis.

\section{Pedagogical Wisdom}

The authors call upon us to collectively cultivate "a repertoire of pedagogical wisdom" (p. 41) as scholarly-practitioners, where we draw from, and simultaneously create, practical wisdom. By responding to emergent learning needs and the embedded "dilemmas" and "pressure points" (p. 11), teaching is framed as a deliberate and well-informed "improvisation" (p. 33). Chapters 3 and 4 provide a more detailed consideration of some common dilemmas faced by educators in practice. The "differential in engagement" (p. 51) among learners and teachers considers the complexity of various levels and motivations that can further lead to disruptions in teaching and learning. Disconnection can also occur in the varieties of curricula (intended, taught, learned, and assessed), differentiation and personalized learning, and our obsession with "measurement mania" (p. 58) to document learning.

\section{Theoretical Understanding}

The theoretical understanding section presents theory as a partner to practical wisdom. The authors suggest we consider and articulate the theory underpinning that provides a solid base for best-informed spontaneous response in practice. Theory and practice generate the knowledge, collectively, in a fluid interplay.

New articles in this journal are licensed under a Creative Commons Attribution 4.0 United States License.

ULS

This journal is published by the University Library System of the University of Pittsburgh as part of its D-Scribe Digital Publishing Program and is cosponsored by the University of Pittsburgh Press.

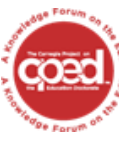

This journal is supported by the Carnegie Project on the Education Doctorate: A Knowledge Forum on the EdD (CPED) cpedinitiative.org 


\section{Contextual Literacy}

The authors refer to contextual literacy as the ability to perceive and understand various of messages across macro (state, nation, and world), mezzo (district and community), and micro (classroom and school) contexts that influence education (p. 137). Education, both in practice and policy, is replete with "contestation" (p. 142) among stakeholders, fueled by varying values and beliefs, perceptions and inconsistent information. The authors suggest that our cultural and individual stories are important lenses to come to know ourselves and others better and make sense of what we encounter.

\section{Ethical Stewardship}

Ethical stewardship of the profession is discussed in three major strands of activity. First, scholarly-practitioners should serve as exemplars of moral and ethical conduct. This suggestion is fairly straightforward as we consider how we represent not only ourselves, but also, our colleagues, and the profession as a community. The authors press this notion forward in two additional, and interesting ways. First, they advise us to be advocates for the profession, beyond the more technical representations of practice, to the more value-driven agenda of equity and justice, learning for all, and in support of educators as professionals. The authors further recommend a "commitment to inquiry" as a critical component of ethical stewardship. This area is explored more fully in a separate chapter in this section that offers a brief overview (epistemologically and ontologically) of the scientific, critical, and interpretive traditions of inquiry (p. 189-197). The section concludes with an additional plea for the importance of narrative inquiry as particularly well-suited for the self-inquiry and reflection of praxis.

\section{Metacognitive Reflection}

The authors offer an interesting and inviting lens on reflection and its relation to learning. Metacognitive reflection is offered as a process of immersion in the experience, with elements of retrospective, introspective, and finally, conceptual reflection. Immersion in the experience harkens back to the earlier exploration of praxis and the essential "being" in practice that carries with it an ongoing critique or reflective quality. Retrospective reflection serves as the narrative of memory of what happened and how, often the narratives we share with others about an experience. Introspective reflection and conceptual reflection call us to more thoroughly interrogate or consider the experience in both what we hoped for it to be and how it fits into the larger plan for what we want to achieve. The authors further encourage practitioners to engage in a more formal metacognitive reflection "process for moving systematically and critically between doing and understanding" (p. 221) by capturing and sharing one's own narratives of teaching and learning.

\section{Aesthetic Imagination}

Continuing with a press toward meaningful and shared reflection as a scholar-practitioner, the authors suggest that a variety of aesthetic modalities may be useful to both explore and represent one's professional journey. The section offers a brief overview of a variety of ways in which scholar-practitioners might consider sharing their ways of knowing with colleagues and others, as well as exploring "possible worlds and possible selves" (p. 249) evolving in practice.

\section{Recommendation}

On Being offers an interesting and compelling guide for educators becoming scholar-practitioners, whether as graduates, graduate students, higher education faculty, or any educator called to developing practical-scholarly wisdom. Indeed, the authors envision that the book might be used to "catalyze discussions in a variety of contexts" hoping that educators from various experiences and perspectives will "resonate with the ideas explored in this book" (p. 13).

The interpretive lens offered throughout the book provides an inviting counter-narrative to the more scientific lens of some literature in the field that focuses on the professional roles and functions of practitioners and the more scientific inquiry modes often embraced. For example, "improvement science" essentially draws from seminal work in improvement processes done during the early-mid 20th century height of scientific rationality by Walter Shewhart and further extended by William E. Deming ${ }^{1}$. This book invites scholar-practitioners to engage in the journey of praxis, to deeply and theoretically reflect on those processes for both professional growth and improvement, and to find ways of sharing that growth with the profession. As such, it perhaps, has an appeal to those who see the journey as important as the outcome; the process as perhaps an improvement outcome itself.

Piantanida, McMahon, and Llewellyn know from whence they speak. It was refreshing to read their own and colleagues' examples within the narrative that help to illustrate and offer vignettes drawn from the landscape of practice. So too, the book stands well in the literature of the field, past and present, to align with conceptual knowledge feeding the movement toward the Education Doctorate. It serves as a good example of the interplay we value as a community in the merger of practice and scholarship. The authors also have offered several useful references and reflective prompts at the end of chapters and sections that might be very useful if used as a text for a class or community of

${ }^{1}$ Lewis (2015) and LeMahieu, Bryk, Grunow, \& Gomez (2017) for more current application in education. 
practice. Whether as a text for self-study or class use, this book offers a useful and insightful lens for the kind of meaningful and insightful reflection the authors suggest we should embrace as scholarly practitioners.

\section{REFERENCES}

Lewis, C. (2015). What Is Improvement Science? Do We Need It in Education? Educational Researcher, 44(1), 54-61. https://doi.org/10.3102/0013189X15570388

LeMahieu, P., Bryk, A., Grunow, A. and Gomez, L. (2017), "Working to improve: seven approaches to improvement science in education", Quality Assurance in Education, Vol. 25 No. 1, pp. 2-4. https://doi.org/10.1108/QAE-12-2016-0086

Perry, J. A. (2012). To Ed.D. or not to Ed.D? Kappan, 94(1), 41-44.

Schwandt, T. (2002). Evaluation practice reconsidered. New York: Peter Lang Publishing, Inc.

Shulman, L. S., Golde, C. M., Bueschel, A. C., \& Garabedian, K. J. (2006). Reclaiming Education's Doctorates: A Critique and a Proposal. Educational Researcher, 35(3), 25-32. https://doi.org/10.3102/0013189X035003025 